\title{
Analysis of Production Factors Affecting Intercropping of Corn and Peanuts in The Pandemic Era (Case Study in Katikupialang, Patawang Village, Umalulu District, East Sumba, Indonesia)
}

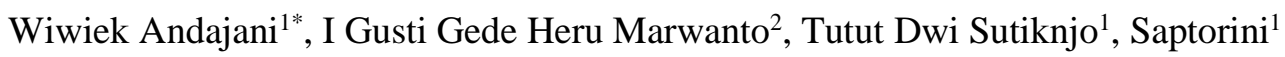 \\ ${ }^{1}$ Department of Agibusiness, Faculty of Agriculture, Kadiri University, Indonesia \\ ${ }^{2}$ Department of Management, Faculty of Economy, Kadiri University, Indonesia \\ ${ }^{1}$ Department of Agibusiness, Faculty of Agriculture, Kadiri University, Indonesia \\ ${ }^{1}$ Department of Agrotechnology, Faculty of Agriculture, Kadiri University, Indonesia
}

\begin{abstract}
In national development in Indonesia, the agricultural sector is still a very decisive economic force, because around 100 million Indonesians work in the agricultural sector. During this pandemic, support is needed for economic recovery, including how to maintain the availability of sufficient food for the community. Efforts to support food security, among others, by increasing the use of land that is more optimal, and also reducing the risk of crop failure, including the intercropping farming system. The objectives of this study were (1) to determine the production factors that influenced the intercropping of corn and peanuts, (2) to determine the production factors (land area, seeds, fertilizers, drugs and labor) which had the most dominant influence on the intercropping of corn and peanuts. In determining the research area, East Nusa Tenggara deliberately chose East Nusa Tenggara, because it has criteria in accordance with the research objectives, namely Patawang Village, Umalulu District, East Sumba Regency, East Nusa Tenggara, where the staple food of most of the population is maize, and the sampling is done census, where the population is small so that all populations are taken as samples, namely 15 samples. The data analysis uses cost analysis, revenue analysis and income or profit analysis, while to test the hypothesis using: (1) multiple regression analysis, (2) multiple correlation analysis, and (3) partial correlation analysis. From the results of the discussion, it can be concluded that together the production factors of land area, seeds, fertilizer, medicines and labor affect the intercropping of corn and peanuts, and fertilizer is the production factor that most influences it. Suggestions for holding training in making good organic fertilizers, from livestock manure and can be an organic fertilizer business opportunity.
\end{abstract}

Keywords: farming, intercropping, production factor

*Corresponding Author:

E-mail: wiwiekand@unik-kediri.ac.id (Wiwiek Andajani)

Department of Agibusiness, Faculty of Agriculture, Kadiri University, Indonesia

\section{INTRODUCTION}

The economic development is an important part of national development, the main objective of which is to improve the welfare of the people. National development in Indonesia, the agricultural sector is still a very decisive economic force, because around 100 million Indonesians work in the agricultural sector. Global economic development encourages increasingly complex economic conditions and intense competition, thus requiring more effective and efficient businesses. Likewise, in the agricultural sector requires a change from production orientation towards increasing farmer income, this can be done with the right approach, namely with a good farming system, optimal land use utilization, environmentally friendly,
Journal Homepage:

http://ejournal.undwi.ac.id/index.php/jsds
Copyright @ 2021 Dwijendra University. All right reserved. 
and sustainable. The availability of foodstuffs during this pandemic needs special attention, given the limited movements and steps to keep conditions safe. Therefore, there is a need for efforts to support the movement to maintain food security. In addition, there is still a very high risk of failure in the agricultural sector, so it is necessary to have a farming pattern that can reduce this risk, including the intercropping farming system. (Soekartawi, A Soeharjo, John L Dillon, 2011)

Intercropping farming is a cropping system that mixes two or more other plants in one area of planting land, at almost the same time, with the aim of making the most of the land, in the hope of obtaining more yields. The types of plants that can be used in the intercropping system generally use a combination of plants, including planting with companion plants, with repellent plants and with attractive plants (Suryanto,H, Maryunianta Y, 2017). Basically, the intercropping planting pattern is to adhere to a system of mutual support and complementarity between one another. plant with other plants. There are several advantages that exist in the intercropping planting system, among others, are there will be an increase in efficiency (labor, land use and absorption of sunlight).

The plant population can be arranged as desired. In one area, there is production of more than one commodity. Still have a chance to get a result if one crop failed and the combination of several types of plants can create biological stability so that it can reduce pests and diseases can increase soil fertility helping to use the land as optimally as possible minimizes weed growth and climbing (Warsana, 2009). Besides having advantages, the intercropping planting system also has weaknesses, which include: the number of pests that make it difficult to control, plants compete for nutrients. There are obstacles in the plant growth process. Soils are increasingly susceptible to erosion due to the influence of high rainwater content.

The province of East Nusa Tenggara has the potential to develop dry land agriculture, besides that it is also rich in natural resources, which on average are still not contaminated with chemicals, and materials for developing organic systems are available, such as livestock manure. the people are mostly breeders (BBP2TP, 2017). In accordance with the strategic policy of the East Nusa Tenggara provincial government, namely agricultural revitalization, with the main target, is to create resilient agriculture to strengthen food security, especially during a pandemic. The potential of dry land farming is very suitable for corn crops, considering that the staple food for most of the area's population is maize, and one of the potential areas is East Sumba Island, or East Sumba Regency, especially in Patawaang Village, Umalulu District. There are many factors that influence farmers' decisions in determining and working on commodities and their farming system patterns, therefore the objectives of this study are: (1) to determine the production factors that affect the intercropping of corn and peanuts in Patawang Village, Umalulu District, Regency. East Sumba, (2) To determine the production factors (land area, seeds, fertilizers, medicines and labor) which were the most dominant in affecting the intercropping of corn and peanuts.
Journal Homepage:

http://ejournal.undwi.ac.id/index.php/jsds
Copyright @ 2021 Dwijendra University. All right reserved. 


\section{METHODS}

The determination of the research location was purposive (intentionally), on the grounds that in Katikupialang Hamlet, Patawang Village, Umalulu District, East Sumba Regency, NTT, there were farmers who carried out the intercropping pattern of corn and peanuts. In taking the sample using two sampling techniques, the first is purposive sampling technique, which is a sampling technique based on certain considerations and criteria based on the research objectives, namely the sample of farmers who farm using the corn and peanut intercropping system, while the second is non-probability sampling, in this case with Saturated Sampling, where the technique of determining the sample of all populations is used as a sample, this is done because the population is relatively small, less than 30 people. (Sugiyono, 2013) The number of samples is 15 farmers intercropping corn and peanuts.

The method of analysis includes using the descriptive method of analysis, which is to give meaning to the data by describing it in accordance with the current situation.

The cost analysis is obtained from all costs incurred during the farming production process of the corn and peanut intercropping system. The types of costs incurred are fixed costs and variable costs, according to K Suratiyah, 2015 (K. Suratiyah, 2015):

$\mathrm{TC}=\mathrm{FC}+\mathrm{VC}$

The revenue analysis is obtained from the multiplication result between the amount of production and the selling price of the production, both revenue from corn and peanut. Revenue analysis (Astuti et al., 2019):

$\mathrm{TR}=\mathrm{P} \times \mathrm{Q}$
Meanwhile, the income or profit analysis is obtained from the difference between the revenue and the total cost of farming, both from corn and peanut, as in the formula below.

$\pi=\mathrm{TR}-\mathrm{TC}$

Hypothesis test analysis using:

Multiple Regression Analysis (Sugiyono, 2014):

$\mathrm{Y}=\mathrm{a}+\mathrm{b} 1 \mathrm{X} 1+\mathrm{b} 2 \mathrm{X} 2+\mathrm{b} 3 \mathrm{X} 3+\ldots+\mathrm{bnXn}$ .................. (4)

Multiple Correlation Analysis (Simultaneous):

Ry. $x_{1} x_{2} x_{3}=\sqrt{\frac{r^{2} y x_{1}+r^{2} y x_{2}+r^{2} y x_{3}+r^{2} y x_{4}-2 r y x_{1} \cdot 2 r y x_{2} \cdot 2 r y x_{3} 22 r y x_{4}}{1-r^{2} x_{1} x_{2} x_{3} x_{4}}}$

To determine the strength of the relationship between the two variables using the partial correlation analysis method or Pearson Product Moment Correlation Analysis with the formula:

$$
r_{x y}=\frac{n \Sigma x_{i} y_{i}-\left(\Sigma x_{i}\right)\left(\Sigma y_{i}\right)}{\sqrt{\left.\sqrt{(n \Sigma} x_{i}^{2}-\left(\Sigma x_{i}\right)^{2}\right\}-\left\{n \Sigma y_{i}^{2}-\left(\Sigma y_{i}\right)^{2}\right.}}
$$

\section{Hypothesis}

It is suspected that the production factor of land area, seeds, fertilizers, medicines and labor affects the intercropping of corn and peanuts.

It is assumed that the production factor of land area has the most influence on the intercropping of corn and peanuts.

\section{RESULTS AND DISCUSSION}

\subsection{General Condition of the Research Area}

Patawang Village is one of 9 villages in Umalulu District, which was formerly known as Tana Umalulu, where most of the people are farming and raising livestock. The area of Katikupialang Hamlet, Patawang Village, Umalulu District, East
Journal Homepage:

http://ejournal.undwi.ac.id/index.php/jsds
Copyright (C) 2021 Dwijendra University. All right reserved. 
Journal of Sustainable Development Science

Vol. 3, No. 1, June 2021, pp. 17-25

e-ISSN: 2715-9140| p-ISSN: 2722-919X

Sumba Regency, is 199 hectares and has a population of 1,594 people, with the

The boundaries can be seen in the table majority of the population being breeders. below.

TABLE I

Administrative Boundaries of Katikupialang Hamlet

\begin{tabular}{|c|c|c|}
\hline $\begin{array}{c}\text { Administrative } \\
\text { Boundaries }\end{array}$ & Village/Location & Districts \\
\hline North & Sugar cane plantation & Umalulu \\
South & Sugar cane plantation & Umalulu \\
East & Residential & Umalulu \\
West & Sugar cane plantation & Umalulu \\
\hline
\end{tabular}

Source: Katikupialang Hamlet Profil (2020)

The location of the Katikupialang hamlet is $3 \mathrm{~km}$ from the district center, and $5 \mathrm{~km}$ from the district center.

\subsubsection{Condition of Agriculture}

The distribution of land use can be seen in the table below.

TABLE II

Distribution of Land Use in Katikupialang Hamlet

\begin{tabular}{|c|c|c|}
\hline No & Land Use & Area \\
\hline 1. & Rice fields & \\
\hline & a. Technical irrigation & $70 \mathrm{Ha}$ \\
\hline & b. Rain-fed & $100 \mathrm{Ha}$ \\
\hline 2. & Dry land & \\
\hline & a. Field & $300 \mathrm{Ha}$ \\
\hline & b. Settlement & $80 \mathrm{Ha}$ \\
\hline & c. Yard & $70 \mathrm{Ha}$ \\
\hline 3. & Public facilities & \\
\hline & a. Government office & $3 \mathrm{Ha}$ \\
\hline & b. Schools & $1 \mathrm{Ha}$ \\
\hline & Total & $624 \mathrm{Ha}$ \\
\hline
\end{tabular}

\subsubsection{Agriculture Production}

Lowland rice production, 4 tons / Ha covering an area of $100 \mathrm{Ha}$, while the second production yield is corn commodity of 3 tons / Ha with a land area of $35 \mathrm{Ha}$.

\subsubsection{Demography}

From the data from the profile of Katikupialang hamlet, 2020, the total population is 700 , consisting of 500 families, where based on gender, 352 people are male and 348 are female. While based on age can be seen in the table below.

TABLE III

Population Composition Based on Education Level

$\quad$ Education Level
Pre-school $(3-6)$ years old
School-age $(7-18)$ years old
Primary school
Junior high school
Senior high school
College degree
Bachelor degree
$18-56$ years old (did not finish primary school)
$12-56$ years old (did not finish junior high school)
Total

Total

\begin{tabular}{|c|c|}
\hline Male & Female \\
\hline 12 & 9 \\
97 & 91 \\
105 & 90 \\
5 & 7 \\
50 & 31 \\
2 & 1 \\
5 & 4 \\
40 & 21 \\
50 & 80 \\
366 & 334 \\
\hline
\end{tabular}

Journal Homepage:

http://ejournal.undwi.ac.id/index.php/jsds
Copyright $@ 2021$ Dwijendra University. All right reserved. 
Journal of Sustainable Development Science

Vol. 3, No. 1, June 2021, pp. 17-25

e-ISSN: 2715-9140| p-ISSN: 2722-919X

Source: Katikupialang Hamlet Profil (2020)

The population composition based on the livelihoods of the residents of Katikupialang hamlet, Umalulu District, East Sumba Regency can be seen in the table below.

TABLE IV

Population Composition Based on Livelihoods

\begin{tabular}{|c|c|c|}
\hline Job & Male & Female \\
\hline Farmer & 230 & 40 \\
Breeder & 279 & 33 \\
Fisherman & 50 & 3 \\
Others & 65 & 76 \\
Total & 624 & \\
\hline
\end{tabular}

Source: Katikupialang Hamlet Profil (2020)

\subsection{Sample Farmers' Characteristics}

Profiles of sample farmers who cultivate the intercropping system of corn and peanuts in Katikupialang Hamlet, Patawang Village, Umalulu District, Sumba
Timu Regency, starting from land ownership, age, education level, number of dependent families and farming experience can be seen in the table below.

Table V

Characteristics of Sample Farmers Based on Land Size in Katikupialang Hamlet

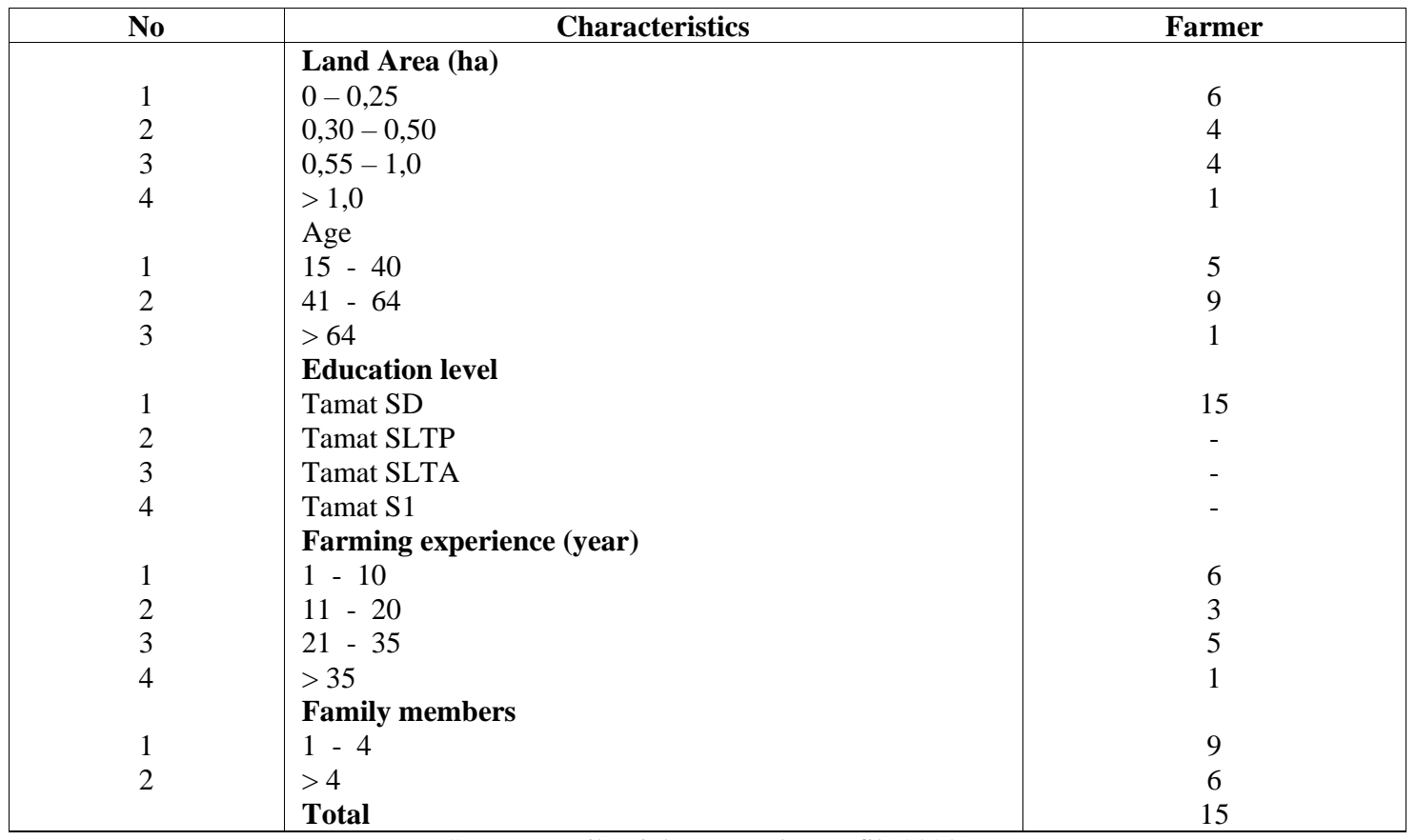

Source: Katikupialang Hamlet Profil (2020)

\subsection{Intercropping Cultivation}

Some of the conditions that must be met in a intercropping farming system include:

a. Intercropping plants must be able to support the development of other plants and compete with each other

b. When to implement the intercropping system must be adjusted, for example for corn and peanuts, preferably in the 
month that has entered the dry season.

\subsubsection{Land Processing}

The soil is processed $10-15 \mathrm{~cm}$ deep, then mounds are made, with the direction of the mounds facing west east or adapted to land conditions. The width of the mounds is $170-180 \mathrm{~cm}$ and the length is according to the needs, and between the mounds a $20-30 \mathrm{~cm}$ channel is made to drain the water.

\subsubsection{Planting}

In this intercropping system, peanuts are planted first before planting corn, with a spacing of peanuts of $25 \times 25 \mathrm{~cm}$, and a hole depth of about $3 \mathrm{~cm}$ and filled with 2 peanut seeds (in the model of being stuck). After the peanut plant has several leaves (about 3 weeks old), a new hole is made in the mound to plant the corn, before planting the corn seeds a seed treatment is carried out. The planting hole is made 2-3 $\mathrm{cm}$ deep by means of baffling, with $200 \mathrm{~cm}$ spacing between rows of plants and $40 \mathrm{~cm}$ apart, so that each mound contains 1 row of corn and 5 rows of peanuts.

Corn root is symbiotic with peanuts, it will immediately absorb as much nitrogen as possible, then it will quickly grow big. Then irrigation can be done occasionally on the beds at intervals of 10-14 days

\subsubsection{Fertilization}

Fertilization is done twice, at planting time and when the plants are approximately 1 month old, using manure. The method of fertilizing is made an array near the plant row (about $5 \mathrm{~cm}$ from the row of plants with a depth of 5-7 cm), the fertilizer is sown along the array and then covered again with soil.

\subsubsection{Maintenance}

Plant maintenance includes replanting, weeding and planting. Embroidering for maize is done about 5 days after planting, and for peanuts about 8 days after planting. Weeding and stocking are carried out at least twice or according to weed conditions (grass), using roundup weed medicine. In the second weeding, it is done at the same time, namely by loosening the soil and raising the soil around the stem.

\subsubsection{Harvesting}

The peanut harvest period is about 3 months, by pulling it out, when the soil is wet, while the corn is about 3.5 months, by cutting the corn stalks, and the fruit is directly picked. Then the peanut plants are harvested first.

\subsection{Analysis of Results}

\subsubsection{Analysis of Farming Costs}

The cost of intercropping farming is all costs incurred during the production process of intercropping corn and peanuts, which consists of fixed costs and variable costs. For fixed costs, fixed costs include land tax, land rent, agricultural equipment. Meanwhile, variable costs include costs for the purchase of seeds, fertilizers, medicines, and labor costs. For more details, see the table below
Journal Homepage:

http://ejournal.undwi.ac.id/index.php/jsds
Copyright @ 2021 Dwijendra University. All right reserved. 
Journal of Sustainable Development Science

Vol. 3, No. 1, June 2021, pp. 17-25

e-ISSN: 2715-9140| p-ISSN: 2722-919X

Table VI

The Average Cost of Corn and Peanut Intercropping Farming per Hectare in Katikupialang Hamlet

\begin{tabular}{|c|l|r|}
\hline No & \multicolumn{1}{|c|}{ Cost type } & \multicolumn{1}{|c|}{ Price (IDR) } \\
\hline 1 & Fix cost & 297.000 \\
2 & Variable cost & $646 . .784$ \\
& Seeds & 4.970 .760 \\
& Fertilizer & 618.596 \\
& Pesticide & 320.585 \\
& Labour & 6.853 .725 \\
\hline
\end{tabular}

Source: Primary data

3.4.2 Farming Revenue Analysis

Table VII

The Average of Corn and Peanut Farming Revenue and Income per Hectare in Katikupialang Hamlet

\begin{tabular}{|c|c|c|}
\hline Production (kg) & Price (IDR/kg) & Total \\
\hline Corn (6.095,32) & 3.000 & 18.285 .960 \\
Peanuts (101,58) & 10.000 & 1.015 .800 \\
Revenue & & 19.301 .760 \\
Income & & 12.448 .035 \\
\hline
\end{tabular}

Source: Primary data

3.2 Hypothesis Test

Multiple Regression Test

SUMMAVY OUTPUT

\begin{tabular}{ll}
\hline Regression Satistics & \\
\hline Mutiple R & 0,972381 \\
RSquare & 0,945524 \\
Adjusted R Square & 0,898831 \\
Standard Error & 1888281 \\
Obsenations & 14 \\
\hline
\end{tabular}

Based on the SPSS output table, it is independent variables on the dependent known that the coefficient of determination variable (avocado farming profit rate. or R Square is 0.9455 or $94.55 \%$ which Meanwhile, $5.45 \%$ is influenced by other shows the simultaneous influence of all factors that are not researched.

Multiple Correlation Test

\begin{tabular}{|c|c|c|c|c|c|}
\hline & $d f$ & $\$ S$ & MS & f & Sigrificance $f$ \\
\hline Regression & 6 & $4,33212<+14$ & $7,22021 E+13$ & 20,24960057 & 0,000428248 \\
\hline Residual & 7 & $2,45592 \mathrm{k}+13$ & $3,5656 \mathrm{E}+12$ & & \\
\hline Total & 13 & $4,581726+14$ & & & \\
\hline
\end{tabular}


Based on the value of the F-count (20.2496) which is greater than the F-table (4.21), the hypothesis which states that there are independent variables which together affect the income of corn and peanut intercropping farming is accepted.

\begin{tabular}{|c|c|c|c|c|c|}
\hline & \multicolumn{4}{|c|}{ Partial Correlation Test } & \multirow{3}{*}{$\begin{array}{l}t+4 t e \\
18048\end{array}$} \\
\hline & Coffiers & Stroxtisor & $\operatorname{tst} z$ & Prode & \\
\hline inzos: & 40765 & $4 x(317,8$ & -122245 & 02660644 & \\
\hline 05 & -620 & $16 x(692)=0$ & 0 3xssi73 & 0,70000197 & \\
\hline 2000 & $49 \mathrm{Ex}$ & 402967. & 0.227478 & $0,906 \mathrm{BL} 2 \mathrm{2}$ & \\
\hline 5000 & $5112 x$ & 10,64624 & 4.865079 & 0645462 & \\
\hline 25000 & 92289 & 4276636 & $2 B 56110$ & 0,679028 & \\
\hline 32000 & 45804 & $587 \% 65$ & $0,+2032$ & 0,48285 & \\
\hline жOO & 4523 & 192841116 & $-195913 \%$ & 00.21282 & \\
\hline
\end{tabular}

Based on the results of the calculation (partial test) which is compared with the ttable value (1.98458), it is found that only the fertilizer production factor has a significant (partially) effect on the income of corn and peanut intercropping farming. Meanwhile, other production factors (land area, corn and peanut seeds, medicines and labor) did not have a significant effect.

\section{CONCLUSIONS}

\subsection{Conclusion}

a. The factors of production of land area, seeds, fertilizers, medicines and labor together affect the intercropping of corn and peanuts.

b. The dominant factor of fertilizer production affects the intercropping of corn and peanuts.

\subsection{Suggestions}

a. There needs to be a more optimal increase in the use of land production factors, seeds, medicines and labor in the intercropping of corn and peanuts.

b. Extension or training in making organic fertilizers from livestock manure, to increase human resources, because most farmers use manure in the intercropping of corn and peanuts. It is an opportunity for the organic

c. fertilizer business, considering that most people in Patawang Village, Umalulu District, East Sumba Regency, East Nusa Tenggara are raising livestock.

\section{REFERENCES}

Astuti, H. B., Hartono, R. H., \& Rambe, S. S. (2019). Financial Analysis of Maize and JajarLegowoIntercroping System of Maize-Soybean in Seluma Districk. Jurnal AGRISEP : Kajian Masalah Sosial Ekonomi Pertanian Dan Agribisnis, 18(1), 107-114. https://doi.org/10.31186/jagrisep.18.1.10 7-114

BBP2TP. (2017). Ungkit Pembangunan Pertanian di Perbatasan Nusa Tenggara Timur. Bbp2tp.Litbang.Pertanian.Go.Id. http://bbp2tp.litbang.pertanian.go.id/inde x.php/berita/berita-aktual/258-inovasidan-sinergi-ungkit-pembangunanpertanian-di-perbatasan-ntt

K. Suratiyah. (2015). Ilmu Usahatani. Penebar Swadaya.

Soekartawi, A Soeharjo, John L Dillon, J. B. H. (2011). Ilmu Usahatani dan Penelitian Untuk Pengembangan Petani Kecil. Universitas Indonesia.

Sugiyono. (2013). Metode Penelitian Kuantitatif, Kualitatif dan $R \& D . C V$. Alfabeta.
Journal Homepage:

http://ejournal.undwi.ac.id/index.php/jsds 
Journal of Sustainable Development Science

Vol. 3, No. 1, June 2021, pp. 17-25

e-ISSN: 2715-9140| p-ISSN: 2722-919X

Sugiyono. (2014). Metode Penelitian Kuantitatif, Kualitatif dan $R \& D$. Alfabeta.

Suryanto,H, Maryunianta Y, A. S. F. (2017) 'Analisis Perbandingan Usahatani Antara Pola Tanam Tumpang Sari Cabai Merah Keriting Dan Kubis Krop Dengan Monokultu Cabai Merah Keriting di Desa Parbuluan, Kecamatan Parbuluan, Kabupaten Dairi. Journal On Social Economic of Agriculture And Agribusiness, 8(1).

Warsana. (2009). Introduksi Teknologi Tumpang Sari Jagung dan Kacang Tanah. Penebar Swadaya. 